\title{
The Drosophilidae (Diptera) of Estonia
}

\author{
Stefan A. Escher, Johan Ekenstedt, Kaupo Elberg and Anssi Saura*
}

Escher, S. A, Ekenstedt, J., Elberg, K. \& Saura, A. 2006: The Drosophilidae (Diptera) of Estonia. — Entomol. Fennica 17: 13-20.

Until recently, no published records on drosophilids from the Baltic countries existed, except for an unpublished species list for Estonia. We made two collecting trips through the three Baltic countries in the summer of 2000. The first trip was made in early summer to get spring species and the second in late August to get the fungivorous species. We used baiting methods for collecting Drosophila, while the earlier results were obtained e.g. using net sweeping. In general, the drosophilid fauna of Estonia resembles the well-known fauna of the Nordic countries. The single most interesting result was that Chymomyza amoena, a recent American invader of central Europe, was found. Another interesting finding was the relative rarity of $D$. subobscura and the virtual absence of $D$. virilis group species.

S. A. Escher, J. Ekenstedt \& A. Saura, Department of Molecular Biology, Umeå University, SE-901 87 Umeå, Sweden; correspondent author's e-mail: anssi.saura@molbiol.umu.se

K. Elberg, Institute of Zoology and Hydrobiology, University of Tartu, Vanemuise 46, EE-51014 Tartu, Estonia

Received 8 March 2005, accepted 2 May 2005

\section{Introduction}

The genus Drosophila is by far the best known group of insects. Drosophila melanogaster Meigen is a model organism of the genome project. The sheer weight of the ever accumulating knowledge has effectively prevented a revision of an obviously paraphyletic genus, held together with $D$. melanogaster. The rest of the family Drosophilidae is held together largely through this paraphyly (Bächli et al. 2004).

The Drosophila story began in northern Europe, with Fabricius describing Musca funebris in Denmark in 1787. Fallén, working in Sweden, transferred this species to a new genus, Drosophila, in 1823. This genus was later split into several others, with Hackman, in Finland, being a specialist on Scaptomyza. The breakthrough in
Drosophila biology took place in North America: Morgan and his students, with Sturtevant and Dobzhansky, pioneer-worked on the biology and evolution of these small flies. At that time it seemed that the Russians were catching up, with Chetverikov, Dubinin and Timofeeff-Ressovsky laying the groundwork of evolutionary genetics. History took, however, another way. We have data on drosophilids from Finland (Hackman 1954), the St. Petersburg area (Shtakelberg 1930, Hackman 1957) and Denmark (Frydenberg 1956), and we have recently completed an overview of a North European drosophilid fauna (Bächli et al. 2004). The importance of this family in all biology makes publishing a review of Estonian drosophilids timely. To give an example, while D. subobscura occurs in the St Petersburg area and all the way to Moscow (Saura et al. 
1998) and Kazakhstan (Gornostaev 1993) and over the rest of Europe, the attempts to describe the situation in the Baltic countries have just been guesses (e.g. Krimbas 1993).

The drosophilid fauna of Estonia is, in fact, well known. Kunberg (1981) has written a short monograph, with records on biology in Estonia. His study has, however, remained an unpublished thesis written in Estonian. The authors Escher, Ekenstedt and Saura have collected additional material. We may also mention that the specimen of D. busckii that we collected at a garbage container at the harbour of Tallinn has figured greatly in the study of identifying a novel system of gene regulation (Larsson et al. 2001), and its chromosomes have been used to illustrate the concept of epigenetics in a special issue of the journal Science (Riddihough \& Pennisi 2001). All information on Drosophila biology is valuable, and we believe that the species list of Estonia will lead to further studies.

\section{Material and methods}

The material for this report was collected by the authors in June and August 2000. All other information is derived from the unpublished thesis of Kunberg (1981). He used both net sweeping and baits to collect Drosophila.

We collected flies from as many biotopes as possible, including dust bins, mushrooms and felled logs, using either net sweeping or suction in fermenting baits with rotting bananas and other fruits. Depending e.g. on weather conditions, the traps were checked after at least once an hour. After preliminary examination of the flies in the field, they were stored in ethanol and further examined in the lab.

We made a special effort to get specimens of the virilis group by collecting along the banks of small and large rivers.

\section{Results and discussion}

The results are given in the accompanying species list, where certain species are highlighted. In general, there was nothing completely unexpected compared with the well-known droso- philid fauna of the Nordic countries (e.g. Hackman 1954, Frydenberg 1956). The subarctic and alpine species were, of course, missing.

We found some Chymomyza amoena. This is a recent North American immigrant to central and southern Europe (e.g. Band et al. 1999) Another remarkable result was the almost complete absence of specimens of the virilis group. The riverside habitats hosted mostly domestic species, in particular D. melanogaster. D. subobscura was also remarkably scarce. In habitats where we expected it, we got mostly $D$. obscura in very large numbers. This contrasts with observations from southern Finland in central Sweden.

As for the four species of the $D$. virilis group found in Sweden and in Finland, D. lummei and D. ezoana have virtually disappeared from Finland and from Sweden, and also D. littoralis and D. montana have become uncommon. D. subobscura had disappeared from the sites in Sweden and in Finland where we collected the species in 1994. Earlier it was actively spreading towards the north and had become common and abundant (Saura 1995). Currently its distribution seems to decrease. It is unclear what has happened with these species. However, laboratory strains are available from the period before the population crash and there are also a vast amounts of unpublished enzyme allele frequency data from Norway, Sweden and Finland from mid 1970's. These may allow an evaluation of possible genetic consequences of the drastic decrease, e.g. via comparing allele frequencies (and DNAs) before and after the crash.

\section{An annotated list of species}

\subsection{Genus Amiota Loew, 1862}

Amiota is a very large genus, with 44 Palaearctic species; most of which live in the eastern Palearctic (Bächli \& Rocha Pité 1981). The species presented here belongs to the subgenus Amiota Loew, 1862.

\section{A. alboguttata (Wahlberg, 1839)}

Kunberg (1981) reports this species from UusKasaritsa (Võru area). This is a widespread but rather uncommon species in northern Europe. It 
comes to fermenting baits, and lives among the foliage of trees.

\subsection{Genus Chymomyza Czerny, 1903}

C. caudatula, C. costata and C. fuscimana are independent of human culture, i.e. "wild" species. All have larval diapause. They come to fermenting baits and can be cultured on Drosophila medium. They are attracted to freshly-cut surfaces of felled logs in early summer. They engage in lengthy and highly visible courtship behavior and are easily collected with an exhaustor.

There is a monograph on niche shifts and sympatry in the genus (Band 1996) and another on the diapause, cold-hardiness and circadian eclosion rhythm (Riihimaa 1996).

\section{C. amoena (Loew, 1862)}

Tartu, 13.VI.2000; a park within the city. Fermenting bait. Leg. A. Saura.

C. amoena is a commensal of human culture i.e. "domestic" in Europe. Larvae live in nuts in North America, but in Europe the species has experienced a niche shift in that it now breeds in unripe fruits (Band et al. 1999). This is by far the northernmost record of this species. We have earlier found the species in Lithuania (Escher et al. 2004).

C. caudatula Oldenberg, 1914

Adevere, 13.VI.2000; logs in a deciduous forest. Suction. Leg. A. Saura.

Like $C$. costata (see below), a very widespread species. Both are found from Norway to Japan (Bächli \& Rocha Pité 1981).

C. costata (Zetterstedt, 1838)

Adevere, 13.VI.2000; deciduous forest. Suction over logs. Leg. A. Saura.

This is one of the most common drosophilids in northern Europe (Hackman et al. 1971) that exhibits a cline in the reaction determining the larval diapause (Riihimaa 1996, Riihimaa et al. 1996).

\section{C. fuscimana (Zetterstedt, 1838)}

Adevere, 13 June 2000; deciduous forest. Suction on logs. Leg. A. Saura.

\subsection{Genus Drosophila Fallén, 1823}

\subsubsection{Subgenus Dorsilopha Sturtevant, 1942}

D. busckii Coquillett, 1901

A domestic species that breeds in decaying organic material, in particular potatoes but also mushrooms, etc. Comes to fermenting baits. Can be cultured on modified Drosophila medium. Cosmopolitan. We found them among garbage in wastebaskets in Narva, Otepää and Tallinn. Kunberg (1981) reported D. busckii from Viljandi and Tartu.

\subsubsection{Subgenus Drosophila Fallén, 1823}

D. funebris (Fabricius, 1787)

This species belongs to the funebris species group. Kunberg (1981) noted that this widespread, domestic species is common all over Estonia. We found them among garbage in Narva; in Tartu they came to fermenting baits. They are easy to culture.

\section{D. histrio Meigen, 1830}

This species belongs to the histrio species group. A widespread species that is not common anywhere. It comes to fermenting baits. It can evidently not be cultivated on standard media. The larvae live in mushrooms. Kunberg (1981) reports it from Tartu.

\section{D. immigrans Sturtevant, 1921}

Valga, 21.VIII.2000; deciduous forest. Fermenting bait. Leg. A. Saura.

D. immigrans belongs to the immigrans species group. A widespread, domestic species that breeds in compost heaps, etc. It is easy to cultivate and comes to fermenting baits.

\subsubsection{Subgenus Drosophila, quinaria species subgroup}

This is a uniform group that breeds predominantly on mushrooms. Courtney et al. (1999) described the general biology as a mushroom-feeding drosophilid guild. They are easy to collect on their breeding sites and come readily to fermenting baits; likewise, they are easy to cultivate on standard medium. 
D. kuntzei Duda, 1924

Loobu, Rakvere, 20.VIII.2000; mixed forest. Suction. Leg. A. Saura.

This is the northernmost record for an otherwise central European species. We have earlier found the species also in Lithuania (Escher et al. 2004).

\section{D. limbata v. Roser, 1840}

A rather uncommon species that seems to be associated with decaying plant material and black currant (Ribes nigrum) (A. Saura unpubl.). Kunberg (1981) found the species from the Loo river.

\section{D. phalerata Meigen, 1830.}

Geyspits and Simonenko (1970) and Muona and Lumme (1981) have described the diapause of $D$. phalerata and $D$. transversa (see below). $D$. phalerata goes up in the north to about $65^{\circ} \mathrm{N}$ and to North Africa in the south. We found them in Loobu, Rakvere, Saare, Valga, Lihula and Linnamäe, either on mushrooms or attracted by fermenting bait, in August 2000. Kunberg (1981) reports the species from Saaremaa, Samliku (Pärnu area), Luua, Tartu, Sangaste, Rõuge, Vapramäe and Obinitse.

\section{D. transversa Fallén, 1823}

Spread from Norway across Asia; a northern species (up to $71^{\circ} \mathrm{N}$ ) compared with the former. We caught them either from mushrooms or using fermenting bait in Kiviõli, Kohtla-Järve, Iisaku, Saare, Valga, Lihula, Padise; all in August 2000. Kunberg (1981) reports it from Saaremaa, Saka (Kohtla-Järve area), Kaave, Luua, Samliku (Pärnu area), Tartu, Tähtvere, Vapramäe, Pikasilla and Rõuge.

\subsubsection{Subgenus Drosophila, repleta species group}

\section{D. hydei Sturtevant, 1921}

Narva, 20.VIII.2000; city. Netting over garbage. Leg. A. Saura.

Tallinn, 26.VIII.2000; city. Netting over garbage. Leg. A. Saura.

A widespread, domestic species.
D. repleta Wollaston, 1858

Narva, 20.VIII.2000; city. Netting over garbage close to an urinal. Leg. A. Saura.

A widespread, domestic species, though less common than $D$. hydei. In northern Europe, the two species are human commensals: $D$. hydei breeds in all kinds of garbage and $D$. repleta in urine wells of farms, etc. (Lakovaara \& Itämies 1994).

\section{D. testacea v. Roser, 1840}

Loobu, Rakvere, 20.VIII.2000; mixed forest. Suction over Boletus. Leg. A. Saura.

Udna, Narva, 20.VIII.2000; young mixed forest and lakeshore. Fermenting bait. Leg. A. Saura.

Valga, 21.VIII.2000; deciduous forest. Fermenting bait. Leg. A. Saura.

Padise, 26.VIII.2000; young, wet deciduous forest. Suction on Boletus. Leg. A. Saura.

The species belongs to the testacea subgroup. These small flies breed in mushrooms; they are easy to collect over them and using baits. They are also easy to cultivate. Handling them, however, is difficult, as they are very sensitive to ether. Overwintered flies are generally black, while summer flies are pale yellow. The distribution area covers the Palaearctic. Kunberg (1981) earlier reported the species from Kaave and Luu.

\subsubsection{Subgenus Drosophila, virilis species group}

Four North-European species belong to this group: D. ezoana Takada and Okada, 1957, D. littoralis Meigen, 1830, D. lummei Hackman, 1972 and D. montana Patterson \& Wheeler, 1942. They all inhabit littoral zones of lakes and rivers; only $D$. littoralis is restricted to Europe. $D$. ezoana and $D$. lummei evidently occur across Asia all the way to Japan, while $D$. montana goes even further as it inhabits also much of North America. There is extensive literature on the diapause (e.g. Lumme \& Lakovaara 1983), courtship behavior (Hoikkala \& Lumme 1987, Hoikkala \& Aspi 1993) and eclosion rhythm (Lankinen 1986) on northern European D. virilis group species.

These flies come readily to fermenting baits and are easy to cultivate. Males have rather vari- 
able genital morphology but the females are morphologically indistinguishable. We made a special effort to collect these. The result was a single female from the city moat of Pärnu, caught using a fermenting bait on 16 June 2000. Kunberg (1981) reports " $D$. littoralis" from Saaremaa, Viljandi, Luua (Jõgeva area) and Tartu. Accordingly, we can only note " $D$. virilis" group, indeterminate, from Estonia.

\subsection{Genus Lordiphosa Basden, 1961}

Flies of this group do not come to fermenting baits and they can evidently not be cultivated on standard media either.

\section{L. fenestrarum (Fallén, 1823)}

This is a common species in northern Europe. Kunberg (1981) reported the species from Saaremaa and Solbi (Võru area).

\section{L. nigricolor (Strobl, 1898)}

A rather rare species, found in Finland and the St. Petersburg area as well as in central Europe. Kunberg (1981) found it from Saaremaa,Viljandi, Puhtu, Kaave (Jõgeva area), Musti (Valga area) and Obinitsa (Võru area).

\subsection{Genus Scaptodrosophila Duda, 1924}

S. deflexa (Duda, 1924)

Otepää, 21.VIII.2000; beach and deciduous forest. Fermenting bait. Leg. A. Saura.

Valga, 21.VIII.2000; deciduous forest. Fermenting bait. Leg. A. Saura.

This species comes to fermenting baits and can be cultivated; the larvae go to diapause, the details of which are not known.

\section{S. rufifrons (Loew, 1873)}

Rather uncommon, found in the St. Petersburg area but not in Finland (Hackman 1957). It may have adult diapause. Reported earlier from Tähtvere (Tartu area) by Kunberg (1981).
4.5.1. Subgenus Sophophora Sturtevant, 1939, melanogaster species group / melanogaster subgroup

D. melanogaster Meigen, 1830

The best known insect. A widespread, domestic species that comes to fermenting baits; can also be collected over garbage etc. Kunberg (1981) reports that it is common all over Estonia. We found it, often in great numbers, in about all localities influenced by humans and their garbage.

D. simulans Sturtevant, 1919 is another cosmopolitan and domestic species that very probably occurs in Estonia. In northern Europe it is far less common than D. melanogaster. Only the males can be distinguished from the ones of $D$. melanogaster. We checked routinely all males of melanogaster-group flies but did not find a single $D$. simulans. The best way to find it would be to sweep over fruit shelves of stores in SeptemberNovember and look at the male genitalia under microscope.

\subsubsection{Subgenus Sophophora Sturtevant, 1939, obscura species group}

Flies belonging to this group are dark brown to shiny black. The ventral side of male abdomen is red, that of females, white. All come readily to fermenting baits and are tolerably easy to cultivate. Most are indifferent to human culture. The breeding sites of these often exceedingly common flies remain largely unknown.

In addition to the below-listed species, we expect that D. alpina Burla, 1948 and $D$. subsilvestris Hardy \& Kaneshiro, 1968 will be found in Estonia. They are locally abundant on suitable biotopes in southern Finland. We also have found $D$. subsilvestris Fallen, 1823 from Latvia (Escher et al. 2002).

D. ambigua Pomini, 1940

Lihula, 25.VIII.2000; deciduous forest. Fermenting bait.Leg. A. Saura.

Tallinn, 26.VIII.2000; city. Suction over garbage. Leg. A. Saura.

This is a domestic species in northern Europe. 
D. bifasciata Pomini, 1940

Pärnu, 15.VI.2000 and Valga, 21.VIII.2000; deciduous forest. Fermenting bait. Leg. A. Saura.

Spread from Norway to Japan; most common in northern Scandinavia (Saura 1974). Kunberg (1981) reported the species from Viljandi, Tommuski (Viljandi area), Tartu, Vapramäe (Tartu area) and Elva. These records may, in part, be incorrect, as the key of Shtakelberg (1970), the one that Kunberg used, does not include $D$. subobscura that may have been more common than D. bifasciata.

D. obscura Fallén, 1823

Otepää, 21.VIII.2000; beach and deciduous forest. Fermenting bait. Leg. A. Saura.

Valga, 21.VIII.2000; deciduous forest. Fermenting bait. Leg. A. Saura.

Pärnu, 16.VI.2000; city moat (hundreds of flies). Fermenting bait. Leg. A. Saura.

Tartu, 13.VI.2000; park. Hundreds of flies over fermenting bait. Leg. A. Saura.

Common in northern Europe (Lakovaara and Saura 1971). Kunberg (1981) reported the species from Viljandi.

D. subobscura Collin, 1936

Tartu, 13.VI.2000, city park. Fermenting bait. Leg. A. Saura.

Narva, 20.VIII.2000; city. Suction over rotting apple. Leg. A. Saura.

Otepää, 21.VIII.2000; beach and deciduous forest. Fermenting bait. Leg. A. Saura.

Valga, 21.VIII.2000; deciduous forest. Fermenting bait. Leg. A. Saura.

Pärnu, 16.VI.2000; city moat. Fermenting bait. Leg. A. Saura.

This otherwise common species experienced a population crash in 1994 (Saura et al. 1998) in northern Europe, and the populations are still recovering. We found only single flies.

\subsection{Genus Leucophenga Mik, 1886}

\section{L. quinquemaculata Strobl, 1893}

Otepää, 21.VIII.2000. beach and deciduous forest. Fermenting bait. Leg. A. Saura.

Tartu, 13.VI.2000; city park. Fermenting bait. Leg. A. Saura.
These flies come to fermenting baits. They are spread over northern Europe but are seldom frequent at a locality. The larvae live in mushrooms.

\subsection{Genus Scaptomyza Hardy, 1849}

Hackman (1959) has written a monograph on this genus. Davis (2000) has shown that the genus has originated from Drosophila on the Hawaiian Islands and from there colonized the rest of the world. With the exception of S. pallida, the larvae are leaf miners and some are agricultural pests. The adults may come to fermenting baits.

\subsubsection{Subgenus Scaptomyza Hardy, 1849}

\section{S. flava (Fallén, 1823)}

This is an agricultural pest in many parts of the world. Kunberg (1981) reported the species from Puhtu on 25 July, 1951 and on 14 July, 1969.

S. graminum (Fallén, 1823)

A common species. Kunberg (1981) recorded the species from Saaremaa, Viidumäe, Ruila (Harju area), Treppoja, Puhtu, Luua, Tartu, Uderna (Tartu area), Tähtvere, Sulbi, Pikasilla Rannaküla, Sangaste.

S. griseola (Zetterstedt, 1847)

Kunberg (1981) reported this species from Viidumägi on 8 July, 1967.

\subsubsection{Subgenus Hemiscaptomyza Hackman, 1959}

S. unipunctum (Zetterstedt, 1847)

Found earlier in Sika (Võru area) on 10 September, 1959 (Kunberg 1981).

\subsubsection{Subgenus Parascaptomyza Duda, 1924}

S. pallida (Zetterstedt, 1847)

A commensal of human culture, found in gardens, etc. Comes to fermenting baits and can be cultivated on Drosophila media. Found at 21 localities by Kunberg (1981). 


\subsection{Genus Stegana Meigen, 1830}

\section{S. furta (Linnaeus, 1767)}

This species belongs to the subgenus Stegana Meigen, 1830. The species is idespread in Europe. They do not come to fermenting baits. The larvae live under bark of trees. Kunberg (1981) reported the species from Saaremaa, Puhtu, Kaarepere (Jõgeva area), Viljandi, and Vapramäe (Tartu area).

\section{S. coleoptrata (Scopoli, 1763)}

A widespread species of the subgenus Steganina Wheeler, 1960. The specimens do not come to baits. Kunberg (1981) reported the species from Saaremaa, Ogandi (Hiiumaa), Rannaküla (Tartu area), Rõuge, and Sangaste and Elva.

Acknowledgements. We wish to thank Dr. Aina Karpa from the University of Latvia, and Dr. Saulius Pakalniškis and his co-workers from Akademijos 2 in Vilnius, for their hospitality and help during our collecting trip. We are also grateful to Dr. Gerhard Bächli of the Zoological Museum of the University of Zurich, Switzerland, for sharing his knowledge and helpful suggestions regarding the manuscript.

\section{References}

Bächli, G., Vilela, C., Andersson Escher, S. \& Saura, A. 2004: The Drosophilidae (Diptera) of Fennoscandia. - Fauna Entomologica Scandinavica vol. 39. Brill, Leiden. 362 pp.

Bächli, G. \& Rocha Pité, T. M. 1981: Drosophilidae of the Palearctic Region. - In: Ashburnder, M., Carson, H. L. \& Thompson, jr., J. N. (eds.), The genetics and biology of Drosophila, Vol. 3a: 169-196. Academic Press, London. 429 pp.

Band, H. T. 1996: Sympatry and niche shift among temperate zone Chymomyza (Diptera: Drosophilidae) and the mate recognition controversy. - Evol. Biol. 29: 151214.

Band, H. T., Band, R. N. \& Bächli, G. 1999. Nearctic Chymomyza amoena (Loew) (Diptera: Drosophilidae) remains a domestic species in Switzerland. - Mitteilungen der Schweizerischen Entomologischen Gesellschaft 72: 75-82.

Courtney, S.P., Kibota, T.T. \& Singleton, T.A. 1990: Ecology of mushroom-feeding Drosophilidae. - Adv. Ecol. Res. 20: 225-274.

Davis, T. 2000: On the relationship between the Scaptomyza and the Hawaiian Drosophila. - Hereditas 132: 257-259.
Escher, A. S., Ekenstedt, J., Karpa, A. \& Saura, A. 2002: The Drosophilidae (Diptera) of Latvia. - Latvian Entomologist 39: 62-68.

Escher, A. S., Ekenstedt, J., Pakalniškis, S., Rimšaite, J. \& Saura, A. 2004: The Drosophilidae of Lithuania. Acta Zoologica Lituanica 14: 48-55.

Frydenberg, O. 1956: The Danish species of Drosophila (Dipt.). — Entomologiske Meddelelser 27: 249-294.

Geyspits, K. F. \& Simonenko, N. P. 1970: An experimental analysis of seasonal changes in the photoperiodic reaction of Drosophila phalerata Meig. (Diptera, Drosophilidae). - Entomological Review 49: 46-54.

Gornostaev, N. G. 1993: New species and new records of Drosophilid flies (Diptera, Drosophilidae) from Kazakhstan. - Entomological Review 71: 79-82.

Hackman, W. 1954: Die Drosophila-Arten Finnlands. Notulae Entomologicae 34: 130-139.

Hackman, W. 1957: Beiträge zur Kenntnis der Drosophiliden des Leningradgebietes. - Notulae Entomologicae 37: 17-22.

Hackman, W. 1959: On the genus Scaptomyza Hardy (Dipt., Drosophilidae) with descriptions of new species from various parts of the world. - Acta Zoologica Fennica 97: 1-73.

Hackman, W., Lakovaara, S., Saura, A., Sorsa, M. \& Vepsäläinen, K. 1970: On the biology and karyology of Chymomyza costata Zetterstedt, with reference to the taxonomy and distribution of various species of Chymomyza (Dipt., Drosophilidae). - Annales Entomologici Fennici 36: 1-9.

Hoikkala, A. \& Aspi, J. 1993: Criteria of female mate choice in Drosophila littoralis, D. montana and D. ezoana. - Evolution 47: 768-777.

Hoikkala, A. \& Lumme, J. 1987: The genetic basis of evolution of the male courtship sounds in the Drosophila virilis group - Evolution 41: 827-845.

Krimbas, C. 1993: Drosophila subobscura biology, genetics and inversion polymorphism. — Dr. Kovacs, Hamburg. $329 \mathrm{pp}$.

Kunberg, V. 1981: Eesti kõdukärblased. — Master's Thesis, Tartu University, Estonia. 38 pp. [In Estonian with Russian summary.]

Lakovaara, S. \& Itämies, J. 1994: Drosophila repleta Wollaston (Diptera, Drosophilidae) new to Finland. — Entomologica Fennica 5: 149-150.

Lakovaara, S. \& Saura, A. 1971: Genetic variation in natural populations of Drosophila obscura. - Genetics 69: $377-382$.

Lankinen, P. 1986: Geographical variation in circadian eclosion rhythm and photoperiodic diapause in Drosophila littoralis. — J. Comp. Physiol. 159: 123142.

Larsson, J., Don Chen, J., Rasheva, V. Rasmuson-Lestander, Å., \& Pirrotta, V. 2001: Painting of fourth, a chromosome-specific protein of Drosophila. - Proc. Natl. Acad. Sci USA 98: 6273-6278.

Lumme, J. \& Lakovaara, S. 1983: Seasonality and diapause in drosophilids. - In: Ashburner, M., Carson, H.L. \& Thompson, jr., J.N. (eds.), The genetics and 
biology of Drosophila, Vol. 3d: 171-220. Academic Press, London. 428 pp.

Muona, O. \& Lumme, J. 1981: Geographical variation in the reproductive cycle and photoperiodic diapause of Drosophila phalerata and D. transversa (Drosophilidae: Diptera). — Evolution 35: 158-167.

Riddihough, G., \& Pennisi, E. 2001: The evolution of epigenetics. - Science 293: 1063.

Riihimaa, A. 1996: Genetic variation in diapause, coldhardiness and circadian eclosion rhythm in Chymomyza costata. - Acta Universitatis Ouluensis A 274: $1-50$.

Riihimaa, A., Kimura, M. T, Lumme, J. \& Lakovaara, S. 1996: Geographic variation in the larval diapause in Chymomyza costata (Diptera; Drosophilidae). Hereditas 124: 151-163.

Saura, A. 1974: Genic variation in Scandinavian popula- tions of Drosophila bifasciata. — Hereditas 76: 161172.

Saura, A. 1995: Genetic load and population size in northern populations of Drosophila subobscura. - In: Levine, L. (ed.), Genetics of natural populations: 175185. Columbia Univ. Press, New York. 399 pp.

Saura, A., Johansson, B., Lokki, J., \& Kohonen-Corish, M. 1998: Genetic load in marginal populations of Drosophila subobscura. - Hereditas 129: 283-286.

Shtakelberg, A. A. 1930: (The Drosophilidae fauna of Ingria). - Russkie Entomologizhseskie Obozrenie 24: 63-66. [In Russian.]

Shtakelberg, A. A. 1970: (97. Family Drosophilidae - fruit flies). — In: Bej-Bienko, G. Ya. (ed.), (A determining guide of insects of the European part of the Soviet Union in five volumes): 390-399. Nauka, Leningrad. [In Russian.] 